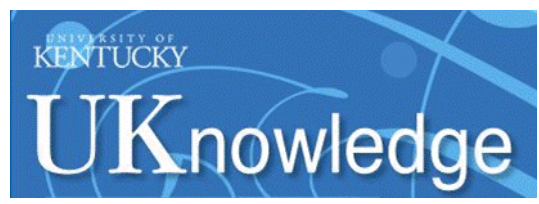

University of Kentucky

UKnowledge

Information Science Faculty Publications

Information Science

$7-2016$

\title{
"For All the People": Public Library Directors Interpret Intellectual Freedom
}

Shannon M. Oltmann

University of Kentucky, shannon.oltmann@uky.edu

Follow this and additional works at: https://uknowledge.uky.edu/slis_facpub

Part of the Library and Information Science Commons

Right click to open a feedback form in a new tab to let us know how this document benefits you.

\section{Repository Citation}

Oltmann, Shannon M., "'“For All the People": Public Library Directors Interpret Intellectual Freedom" (2016). Information Science Faculty Publications. 31.

https://uknowledge.uky.edu/slis_facpub/31

This Article is brought to you for free and open access by the Information Science at UKnowledge. It has been accepted for inclusion in Information Science Faculty Publications by an authorized administrator of UKnowledge. For more information, please contact UKnowledge@lsv.uky.edu. 


\section{“For All the People": Public Library Directors Interpret Intellectual Freedom \\ Digital Object Identifier (DOI)}

https://doi.org/10.1086/686675

Notes/Citation Information

Published in The Library Quarterly, v. 86, no. 3, p. 290-312.

(๑) 2016 by The University of Chicago. All rights reserved.

The copyright holder has granted the permission for posting the article here. 


\title{
"For All the People": Public Library Directors Interpret Intellectual Freedom
}

\section{Shannon M. Oltmann}

\begin{abstract}
Intellectual freedom is frequently seen as a core value of librarianship, especially by the American Library Association, which has issued extensive guidance to libraries about implementing intellectual freedom. Some scholars criticize these documents, arguing that they are unrealistic and do not offer meaningful support to libraries. While scholars question the value of ALA policies, it is unclear whether practicing librarians have similar concerns about the Library Bill of Rights (LBR) and related guidelines. This article describes a study of public libraries and their interpretation of the LBR in their daily practice. To investigate the role played by ALA documents, 15 public library directors across one state were interviewed. In general, the library directors did not directly cite or quote from ALA documents, yet their stances echoed ALA guidance. In addition, library directors frequently discussed the significance of community in their interpretations and implementations of intellectual freedom.
\end{abstract}

ntellectual freedom (IF) is a core value of librarianship, according to the American Library Association (ALA). It has been defined as "the right of every individual to both seek and receive information from all points of view without restriction" (ALA 2014g, par. 1). Intellectual freedom is tightly entwined with access to information, particularly in public libraries (see, e.g., Oltmann, 2016). Many scholars and practitioners reiterate the foundational, core nature of IF (e.g., Gorman 2000; Harkovitch, Hirst, and Loomis 2003; Knox 2011; Morrissey 2012). For example, Don Fallis (2007) explains that library professionals' mission 'is essentially to provide members of society with access to the information that they need" (23). Catherine Foster and David McMenemy (2012) note that "access to information" is a universal value of librarians globally, with "intellectual freedom" also frequently recognized.

However, the power and relevance of IF for public librarians remains understudied. Other than work by Michael Harkovitch and colleagues (2003), few studies have directly asked librarians about their perspective on or use of ALA guidance, and the Harkovitch et al. study focused primarily on Internet filtering (see Moody 2004, and Taylor and McMenemy 2012, for

Library Quarterly: Information, Community, Policy, vol. 86, no. 3, pp. 290-312. (c) 2016 by The University of Chicago. All rights reserved. $0024-2519 / 2016 / 8603-0004 \$ 10.00$

290 
international studies). A few studies have noted the absence of such work. Eliza Dresang (2006) explains that "it is difficult for an academic researcher to write confidently about the state of intellectual freedom in relation to libraries because very little scholarly, data-based research exists that would inform a comprehensive analysis about the contemporary situation" (171). In addition to the philosophical, legal, descriptive, and theoretical accounts that Dresang mentions, Emily Knox (2014) notes that "perhaps the most common type of research on intellectual freedom and censorship is written by practitioners and consists primarily of case studies and reflective essays" (16; see also Harkovitch et al. 2003, 368). Most of these works describe recent occurrences at a local library depicted as a case study or a practicing librarian's reflection on the importance of IF. Few provide analytical depth.

The research described here begins to close this gap, with a qualitative study of public library directors across the state of Kentucky; this research uncovers the meaning, interpretation, and application of IF in public libraries in one southern state. In general, most directors expressed views similar to the guidance that has been issued by ALA and the Kentucky Department for Libraries and Archives (KDLA). However, they also articulated complex, multidimensional perspectives on community and its relation to IF, which are not reflected in current official guidance.

\section{Literature Review}

Intellectual Freedom

As Knox (2014) notes, "In contemporary librarianship, the principle upholding intellectual freedom and opposing censorship is codified within the profession" (11). The principle of IF for patrons is elaborated upon and strengthened in the Library Bill of Rights (LBR) and the accompanying official "Interpretations" as well as in the Code of Ethics and other related statements (Wiegand 1996; Cohen and Minow 2006; Dresang 2006).

The first principle of the LBR states that "books and other library resources should be provided for the interest, information, and enlightenment of all people of the community the library serves. Materials should not be excluded because of the origin, background, or views of those contributing to their creation" (ALA 2014i, principle I). The subsequent five principles also address IF and various related topics. Libraries are encouraged to have information "presenting all points of view on current and historical issues," to "challenge censorship," and to resist "abridgment of free expression and free access to ideas" (ALA 2014i, principles II-IV). The fifth principle states that "a person's right to use a library should not be denied or abridged because of origin, age, background, or views." This is often seen as the most controversial principle because of the inclusion of "age" (see, e.g., Fricke, Mathiesen, and Fallis 2000). Finally, the sixth principle of the LBR addresses exhibit spaces and meeting rooms in the context of IF, stating that these spaces must be "available on an equitable basis, regardless 
of the beliefs or affiliations of individuals or groups requesting their use." The ALA then offers 22 interpretations of the LBR (found in the Intellectual Freedom Manual and on the ALA website), designed to answer questions that "arise concerning application of these principles to specific library practices" (ALA 2014h, par. 1). Likewise, most state-level library associations provide support and guidance for libraries in their state. For example, the Kentucky Department of Libraries and Archives offers continuing education classes and sample policy statements to assist Kentucky public libraries.

One aspect of IF that has received a great deal of scrutiny is the use of Internet filters in libraries, particularly public libraries (McCabe 2003; Jaeger, Bertot, and McClure 2004). The use of Internet filters, tied by law to federal e-rates and Library Services and Technology Act funds, has been contentious in the library community. It is unknown how many public libraries use Internet filters or how their use affects IF for patrons. The ALA has taken the stance that filters should not be used whenever possible; if they must be used, because of federal funding, then they should be set at the least restrictive settings.

From the official ALA perspective, IF is a clear and simple principle that all librarians should embrace: defend individuals' right to freely access information and resist efforts to censor or restrict access (see Baldwin 1996, for a critique of this absolutist stance). For example, ALA regards challenges to materials as "a threat to freedom of speech and choice" (ALA 2014b). Whenever library materials are challenged, ALA recommends a formal hearing to address the concerns (ALA 2014e); the organization is strongly opposed to relocating or removing items due to patron concerns. It is not known to what extent this stance is echoed in public libraries.

Some scholars question whether the principle of IF is such a simple matter to implement in public libraries. Harkovitch et al. (2003) report that many librarians in their study "questioned ALA's approach" to intellectual freedom and Internet filtering (372). For example, Martin Fricke, Kay Mathiesen, and Don Fallis (2000) and Fiona Duthie (2010) argue that there are conceivable, sensible reasons for occasional censorship, but the LBR and related documents do not allow for such exceptions. Gordon Baldwin (1996) offers a detailed critique of the LBR, summarized as "it promises more than it can deliver" (7). Shirley A. Wiegand (1996) explains that the LBR is a mixture of rhetoric, rights, and reality, which may be "at times unhelpful and at other times downright misleading” (80). Others note that IF principles are vague, and their application to actual, concrete cases is somewhat unclear (Fallis 2007).

The ALA guidance on IF and its interpretations do not have the force of law and are not mandatory policies that libraries must follow. Nonetheless, this guidance is highly prescriptive and libraries are generally encouraged to follow it. For example, the preamble to the LBR states that "all libraries are forums for information and ideas, and that the following basic policies should guide their services" (ALA 2014i, par. 1). Thus, ALA makes it clear that libraries ought to follow these policies (though there are no penalties for not doing so). 


\section{Community}

In the discussions of IF within the ALA literature, little mention is made of community; the assumption is that the IF principles are universal and can be applied consistently, across all communities. Yet the omission of community is particularly conspicuous when discussing public libraries - simply because public libraries exist to serve their communities. There is an extensive literature, for example, that describes community building and engagement efforts of public libraries (e.g., Willingham 2008; Edwards, Rauseo, and Unger 2011; Scott 2011a, 2011b; Sung, Hepworth, and Ragsdell 2012; Sung and Hepworth 2013). As Rachel Scott (2011b) notes, these community efforts involve "being proactive and thinking about what [libraries] can do to build strong communities and meet the needs of the people" (337) in the community.

The literature describes several ways that libraries serve their communities: offering children's services, creating programming, assisting job seekers, providing educational opportunities, and so on. Several authors mention public libraries' role in providing a broad range of information (Carr 2011; Edwards et al. 2011; Scott 2011a, 2011b). Typical of the literature is Scott (2011a), who writes: "The public library is a democratic equalizer, open to all and providing access to information that helps people improve their individual, family, and community lives" (191). None of these authors explicitly connects IF with providing broad access to a wide range of information; perhaps they believe the concept of IF is embedded within this access model.

What is a community? Within the library literature, community is rarely defined. It is often a taken-for-granted assumption about the people served by a library. Usually communities are understood to be geographically bound groups of people within a particular service area (see, e.g., Jaeger et al. 2011; Scott 2011a, 2011b; Anthony 2014). In the broader literature, there has been extensive research and reflection on the meaning of community, which is too vast to be reviewed here. However, a review of its use in sociology demonstrated that community was most often understood as "a group of persons (a) engaging in social interaction, (b) within a geographic area, and (c) having a common tie or ties" (Goe and Noonan 2006, 457). This perspective aligns with the stance taken by much of the library literature and is the one adopted in this article.

\section{Method}

The data for this project were collected via qualitative face-to-face interviews. This is an effective method for probing "beneath the surface, soliciting detail and providing a holistic understanding of the interviewee's point of view" (Patton 1987, 108). Darren Lilleker (2003) explained that "interviews can provide immense amounts of information that could not be gleaned from official published documents or contemporary media accounts" (208).

Data from the Kentucky Department of Libraries and Archives were used to determine the 20 largest public libraries in the state, based on size of collection. These 20 public library systems are located in the largest urban and suburban areas and in large towns in every region 
of the state. The largest libraries were chosen for two reasons. First, it is more likely that the largest libraries have directors with MLS degrees and exposure to the LBR and to the principles of IF. Second, because these libraries have the largest collections and correspondingly large patron bases, they may be more likely to have experience dealing with IF in their libraries.

Once the 20 largest public library systems were identified, the director of each system was sent a recruitment letter via e-mail with an offer to participate in this study. Fifteen directors consented to be interviewed. Directors were of various races, ages, and genders; tenure in their current position ranged from less than 1 year to more than 10 years. Two directors met with the researcher together, but all other interviews were conducted one-on-one. The interviews lasted an average of 36 minutes (ranging from 13 to 59 minutes) and took place between November 2012 and March 2013. Table 1 lists the pseudonyms of the interviewees and the length of their interviews. Because this research seeks, in part, to understand the role played by official guidelines, it is useful to review them in conjunction with the participants' comments.

The interviews were conducted face-to-face in the directors' offices and were recorded with the participants' permission. The interviews were later transcribed and analyzed with NVivo 9. To protect confidentiality, each participant was given a randomly selected name that has no

Table 1. Pseudonyms of Interviewees and Length of Interviews

\begin{tabular}{lc}
\hline Interviewee & $\begin{array}{c}\text { Length of Interview } \\
\text { (in Minutes and Seconds) }\end{array}$ \\
\hline Aidan & 18.46 \\
Arnold & $58.58^{\mathrm{a}}$ \\
Beth & $58.58^{\mathrm{a}}$ \\
Carson & 28.01 \\
Janelle & 49.27 \\
Jonas & 38.07 \\
Julianna & 37.08 \\
Justin & $12.59^{\mathrm{b}}$ \\
Lilly & 37.15 \\
Luke & 55.44 \\
Miles & 36.46 \\
Patti & 33.19 \\
Roslyn & 29.06 \\
Stanley & 43.50 \\
Tonya & 28.34 \\
& \\
\multicolumn{2}{c}{ a Arnold and Beth were interviewed together. } \\
b Justin's interview was cut short due to a \\
small crisis in his library.
\end{tabular}


correlation with gender. Identifying details in their responses are obfuscated. Selected results are presented below.

\section{Results}

This section summarizes and explains the data from the project. The interviews yielded a wide range of general information about conceptualizations of IF and challenges to library materials as well as more specific, focused examinations of IF-related issues.

\section{Defining IF}

Central to this discussion of IF is the definition of this phrase. As noted earlier, ALA defines intellectual freedom to include the right to "seek and receive information" and to "access all expressions of ideas" (ALA 2014g, par. 1). Intellectual freedom is listed as a core value of librarianship and is one of the "ethical principles that guide the work of librarians" (ALA 2014d, par. 1). The KDLA, the statewide organization for Kentucky libraries, does not offer its own definition of IF, though it has endorsed the LBR, the Freedom to Read statement, and the Freedom to View statement. The principle of IF is mentioned in KDLA collection development sample policies and in guidance offered for library trustees.

All participants in this study offered some definition of IF during the interview. Even Lilly, who had been a library director for less than 1 year and did not have a library background, noted, "I wouldn't say I that I know the nuances or full application but I've heard of it." IF, as both a phrase and an idea, was very familiar to the participants. In general, the library directors had three different perspectives on intellectual freedom: an impersonal, formal view; a personalized perspective; and a community-oriented approach. The formal approach echoed the ideas and concepts of ALA, closely hewing to the official stance of the organization. The personalized perspective tended to involve some personal reflection about or application of the principles of IF; individuals spoke about what IF meant to them. Finally, the communityoriented approach focused on the broader public being served; here we can see the directors' emphasis on the communities their libraries serve.

For the formal approach, consider Jonas, who defined intellectual freedom as, "People can have access to whatever they want [and] make up their own minds. Period, the end of it." Miles stated that it is "the right for every individual to seek information without fear of judgment or repercussion or restriction." Carson added, "I guess for me it means being able to access any materials that you want or need to, in order to pursue your interests and studies or whatever it might be. The bottom line is people are able to think freely and explore." Luke noted that IF includes "the freedom for people to read" as well as "the freedom for people to watch what they want to watch." These quotes reveal an orientation toward a generalized conception of IF, and they are quite similar to ALA's construction ("the right of every individual to both seek and receive information from all points of view without restriction"). 
In contrast, several participants explained IF in a personal manner, such as Janelle, who said, "I want to read things, I want to view things, and I should be allowed to do that. The library should support that as much as it can." Stanley echoed this view, stating, "For me personally, intellectual freedom is about being able to explore any area that I want to, as far as researching or understanding anything ... without being judged for it." Roslyn explained that people should be able to read whatever they want to read, for whatever reason, and no one should be told their choices are inappropriate; she felt this way because "I don't want someone telling me what to read or not to read" (emphasis in original).

Participants also described IF with a community orientation, in terms of serving the broader public. Janelle described intellectual freedom personally but also as a community service, explaining that "there are a wide variety of people in this county and that they have a wide variety of interests and we as a popular materials library are going to attempt to meet the biggest majority of those interests." Aidan noted, "We are here for everybody, and if you want to have a balanced collection you have to be serving everyone in the community." Julianna expanded upon this, asserting that "the library is not here to govern what you read but to provide you opportunities for all kinds of things, and you never know who wants what or why they want something. I think that is one of the things that libraries do really well and if we don't do it then we are doing a disservice to our community because there are so few places out there that are open."

Only one participant had a notably contrarian view of IF. Justin said, "I wouldn't spend any time trying to define it" because he had other, more pressing concerns in directing the daily activities of the library. Except for Justin, participants were unanimous in endorsing IF as a general principle applicable in their libraries. Miles argued that IF is "what we're all about and that's, as far as I can tell, why libraries were created and why they still exist."

\section{Challenges to Library Material}

The library directors were asked how often their library materials were challenged by members of the community; in this discussion, "challenge" meant a formal, written request for reconsideration. The ALA "declares as a matter of firm principle that it is the responsibility of every library to have a clearly defined materials selection policy in written form that reflects the Library Bill of Rights" (ALA 2014C, par. 1). This interpretation also states that "challenged materials that meet the criteria for selection . . . should not be removed under any legal or extra-legal pressure" (par. 2). Coupled with the relevant Code of Ethics statement ("We uphold the principles of intellectual freedom and resist all efforts to censor library resources"), this is a strong stance against removing materials from libraries (ALA 2014d). Implicit in the ALA's guidance is an equivalence drawn between censors and challengers, those who question the inclusion of certain materials in the library. 
Nearly all participants replied that they received few challenges, though as table 2 indicates, the number of challenges varies widely. Aidan indicated his library received a few challenges per month, which would equal two or three dozen over the course of a year. Other directors reporting a high number of challenges include Janelle (6-7 per year) and Tonya (6 per year). However, three participants reported zero challenges (Patti, Roslyn, and Stanley), and two noted only one challenge (Julianna and Miles). It is interesting that, despite this variation, the library directors generally felt the number of challenges they experienced personally was low. In other words, they did not find challenges to be taxing or overwhelming.

Twelve of the 15 participants explicitly noted they had a policy for challenges to library material, typically called a request for reconsideration. As Justin, Tonya, and Stanley noted, most libraries have very similar, "cookie-cutter" policies, based upon recommendations from ALA and the KDLA. Under the heading "Material Selection/Complaints," for example, the KDLA offers three sample policies that libraries can adopt. The policies suggest that patrons should fill out a "Request for Reconsideration of Library Materials" form; the director should then review the item "both in terms of the library's materials selection statement and the opinion of the various reviewing sources used in materials selection." After the director decides whether to keep the item, the patron may appeal to the library board of trustees. A similar process is outlined in ALA's policy guidance "Dealing with Concerns about Library

Table 2. Frequency of Formal Challenges to Library Materials as Estimated by Library Directors

\begin{tabular}{ll}
\hline Participant & How Frequently Library Material Was Challenged \\
\hline Aidan & A few times every month \\
Arnold & N/A \\
Beth & N/A \\
Carson & N/A \\
Janelle & $6-7$ times per year \\
Jonas & $2-3$ times per year \\
Julianna & 1 time per year \\
Justin & $2-4$ times per year \\
Lilly & N/A \\
Luke & $3-4$ times per year \\
Miles & 1 time in past 5 or more years \\
Patti & 0 times in past year \\
Roslyn & 0 times in past 5 or more years \\
Stanley & 0 times in past 5 or more years \\
Tonya & 6 times per year \\
& \\
\hline
\end{tabular}

Note. - N/A indicates that the participant did not answer this question, because the interview veered in a different direction. 
Resources" (2014e). Most directors interviewed indicated that this process is more or less followed in their own libraries. Several noted that they convened an ad hoc committee of library staff to respond to patron concerns before the complaint escalated to the director, thus adding an additional step in the process (Aidan, Arnold, Carson, Janelle, Jonas, Lilly, Luke, Roslyn, and Tonya).

Described in the directors' own words, this process is designed to demonstrate concern for patrons and create a rational, reasonable, and repeatable method of responding. Carson aptly explained this orientation by noting, "We wanted to honor the fact that they had this concern and take it seriously and let them know that we were listening to what they were saying ... and that we have a system in place so it's not just dismissive" of their concerns. The ALA, similarly, notes that librarians should respond "in a respectful and fair manner" (ALA 2014e, par. 1).

When a patron expressed concern or unhappiness about an item, most libraries, according to the directors, began by listening to the concern and offering the patron the request for reconsideration form. Janelle noted that, "if somebody challenges an item, the training for the staff is 'smile and hand them the form.' . . . We're purposely trying to be nonconfrontational." Roslyn estimated that $90 \%$ of her patrons did not take the form, and of those who did take the form, few returned it. Echoing this, Patti said, "Most of the time, [the patrons] just want to tell you. They don't want to get into a bunch of [written] stuff, but they just want you to know how they feel about it."

The next step in the process is that the director and/or a committee of library staff watched or read the material. Then, Aidan explained, "We look at the reviews of the material to see if it's generally accepted in the community and in the literature. We look at how many times it's checked out" to determine whether an item is worth keeping in the collection. Other participants indicated they had a similar process.

Finally, one of three outcomes occurred: the item was removed, the item was relocated, or the item was kept in its original location. The directors reported that library materials were rarely removed completely from circulation. Only one director, Luke, said he had pulled something: "We've pulled one item out of all the ones that have been challenged, and the only reason why it was pulled is because it was so damaged that you couldn't even watch it." Six directors (40\%) indicated that they had relocated items, usually moving something from the children's section to the young adult section or from the teen section to the adult section (Carson, Janelle, Jonas, Julianna, Miles, and Stanley). Julianna explained, "We moved it to a more appropriate collection. It was in the kids' collection and it really needed to be in the juvenile collection, so we moved it. We've done that a couple of times; that's usually where it belongs. It's been miscategorized and put in the wrong collection." Jonas and Stanley, similarly, noted that their library staff decided to move some items that were "inappropriately cataloged" after they were alerted by patrons. Janelle noted that, most of the time, it is "not 
that somebody is wanting us to pull the material but that they are wanting us to change the designation to move it up to a higher reading level."

However, the participants indicated that the most common response to patron requests for reconsideration was to keep the item in its original location while explaining the decision to the patron. For example, Beth said, "I normally just explain that the library is there for everybody." In his responses, Justin emphasized the broad and diverse readership that the library serves by noting, "There is a readership for this material and if you prefer not to read it or have your child read it, you are in a position to control that. But you are not in a position to control someone else's ability to read it." Tonya responded to patrons by referring back to the mission of the public library, explaining that "because we are an organization dedicated to freedom of reading and materials and information, we feel like [the challenged material] needs to stay in the collection." Finally, Roslyn noted the importance of expressing understanding: "I try to let them know that I see both sides. I'm a parent and I want to protect my child. But then again I'm also a librarian who believes everyone should be able to read what they want to read."

These explanations illustrate the participants' beliefs in respecting patrons' concerns and replying in a thoughtful, courteous manner. For example, Miles reported that his library responded to a parent's concern as follows: “We appreciated her interest in the library and her interest in her own child ... and we appreciated that she was being careful and being aware of what her child was reading." This echoes ALA's stance on children's access to library resources: "ALA acknowledges and supports the exercise by parents of their responsibility to guide their own children's reading and viewing” (ALA 2014a, par. 4).

In addition, participants stressed the importance of a balanced, diverse collection when replying to patrons. Luke's comment provides an example of how this was done: "Our staff's pretty good about explaining to people, 'Okay, you find this particular book to be offensive. Perhaps there are other books that you would find perfectly acceptable that other people in the community would find offensive. And if we start pulling everything off the shelf that everybody finds offensive, there's nothing on the shelf.' Our role as a public library is to provide information to the entire community and not just to one portion of the community. And most of the time that works." Tonya echoed this approach, saying that her favorite explanation to "someone who is very conservative in their beliefs" is to clarify that "the same law that guarantees the freedom of information for the material that you are concerned about also gives us the freedom of being able to purchase Christian fiction and nonfiction." Once she explains this to patrons, they "realize that it's across the board, the openness." Again, this is similar to the official stance of ALA, which argues that "librarians have a professional responsibility to be inclusive in collection development" and "this includes content that reflect a diversity of issues, whether they be, for example, political, economic, religious, social, ethnic, or sexual" (ALA 2014f, par. 3). 
Participants were asked about content that was frequently challenged or questioned (even if not via a formal, written challenge), and their answers are summarized in table 3. Most of the library directors thought the primary issue that concerned patrons was sex or sexuality. Luke said, "There was one person that was just horrified about a homosexual orientation of a movie and it was the most violent movie I've ever seen in my life; there were no problems with the violence, though. It's just how people look at the issue." Stanley noted that "all of our counties are very different from each other, [but] the one thing that everybody loses their shirt over is if somebody's gay [i.e., a character in a library book or movie]. That's the only time I've had a complaint."

Lilly described an incident in which a library patron requested the library begin purchasing a gay/lesbian magazine. After talking with staff, Lilly realized the library could not afford to add another magazine at the time, so she explained that to the patron but added the library would begin purchasing the magazine once it was financially possible. Lilly concluded, "I probably didn't have enough time to think about all the ramifications of that, but at the moment, that seemed like the right thing to do. Now I think it will be a controversial matter to have that magazine here."

Another frequent topic of concern was graphic novels. As Janelle noted, young adult literature often deals with controversial or sensitive topics, "and when that is portrayed graphically people have a problem with that. It's also a problem [because of] superhero things. And when you get superhero things you get women in very skin-tight suits and that can cause problems." Luke, Julianna, Miles, and Roslyn all noted that they had moved some graphic novels to the adult section for similar reasons.

50 Shades of Grey was discussed because it was a controversial yet popular book at the time the interviews were conducted. All 15 participants said their library had multiple copies of the book and that the book had extensive holds from people wanting to read the book. Beth noted, "We have it in print, audio, and e-book on at least two platforms." The directors explained that this book was a good example of serving the community, because even though the book did not receive strong reviews, it was in high demand, so libraries carried it. While Julianna was "absolutely astounded" and Patti was "shocked" that they had not received complaints about the book, others noted that the high demand for the book (and the series) indicated a certain level of community acceptance. Roslyn reported that "A lady did bring one [copy of 50 Shades of Grey] back and said 'I cannot believe that you all have this.' But of course she had requested to read it and you can't tell me she didn't know what it was, but we just said, 'well, it's not for everybody.'”

\section{Internet Filtering}

Twelve of the 15 participants reported that their library used Internet filtering to reduce access to pornography and other Internet content. Most directors indicated their library chose to use 
Table 3. Content Types That Are Frequently Challenged, According to Library Directors

\begin{tabular}{|c|c|}
\hline Participant & Content That Is Frequently Challenged or Cause for Patron Concern \\
\hline Aidan & $\begin{array}{l}\text { "A few challenges based on language ... but most of the ones l've seen are because } \\
\text { of sexual orientation." }\end{array}$ \\
\hline Carson & $\begin{array}{l}\text { "As far as the subject matter goes, it was probably more coming-of-age sorts of } \\
\text { issues, you know, sexuality." }\end{array}$ \\
\hline Janelle & $\begin{array}{l}\text { "A particular problem with videos [that are not rated] ... sometimes children's } \\
\text { books are challenged, particularly graphic novels." }\end{array}$ \\
\hline Julianna & $\begin{array}{l}\text { "It's usually a very small point or it's foul language . . . it's usually content [too] } \\
\text { advanced for an age, language, or some incident in the book." }\end{array}$ \\
\hline Luke & $\begin{array}{l}\text { "It tends to be issues of sex and issues of politics. They're our two issues. . . It } \\
\text { usually has to do with homosexuality or sexual issues." }\end{array}$ \\
\hline Miles & "It would be the theme and sometimes the fantasy theme ... and then language." \\
\hline Patti & "Rated-R movies . . s sex, usually." \\
\hline Roslyn & $\begin{array}{l}\text { "It was a graphic novel. ... [Another one] had to do with the slang language from } \\
\text { the Mark Twain era. . . I think [the most common concern] is sex." }\end{array}$ \\
\hline Stanley & "If somebody's gay." \\
\hline Tonya & $\begin{array}{l}\text { "It's a youth something. . . . We had some challenges to R-rated DVDs because } \\
\text { there was graphic sex. . . Sex, that's a good general term. Gay or just graphic." }\end{array}$ \\
\hline
\end{tabular}

filtering as a result of the Children's Internet Protection Act, which tied certain federal funds to the use of Internet filters. Arnold said, "We needed the money. We've sold our soul." But he then elaborated, noting that adult patrons can request the filters be turned off and that filters have become more sophisticated and less prone to error. Carson agreed that the filters have improved. Janelle said, "We have not really had too many problems with the filter. A lot of people take it off [if they have an adult library card]." She explained that her library used Internet filters because "We don't have Playboy on the shelf. Even though that might be a popular interest, we don't see it as something that we are going to collect and so we don't allow our computers to be used that way either." Jonas and several other participants noted that patrons can ask for the filter to be lifted or overridden, and that library staff are very willing to do so.

Justin's comments about Internet filtering stand out; he said patrons "can request all they want but that's not our policy." The Internet use policy at Justin's library does not allow for adults to access the unfiltered Internet, in direct contravention to ALA recommendations. As Anne Klinefelter (2010) noted, "eight of the Justices [on the Supreme Court] found the ability of adult patrons to gain access to protected internet speech to be important to the constitutionality of the library's use of internet software filters" (p. 362). In other words, the ability to turn off the filter upon request was a significant factor in the Children's Internet Protection Act being upheld by the Supreme Court.

The ALA has taken a firm stance opposing Internet filtering, though many librarians are supportive of it. Luke noted that "the initial concept through the [library] system was that we 
weren't going to use filtering. After a week, the librarians changed their minds. . . It was becoming a community issue and a nightmare to try to police it." Similarly, Roslyn commented that, "in our community, I think there are more people who would be upset if we didn't [filter]." Stanley discussed the pain caused to the library and the entire community by a child pornography case:

It was such a devastating incident, not only for us, but it was horrendous for the community. . . . We tried our very best not to filter the computers: [having] an acceptable use policy, [putting] the computers in a very open place. And it was just incredible that this individual managed to literally go around everything that we had and it's not happening again here. It's not the same. We talked about this before we added the filters and all of us feel very strong about our intellectual freedom stance here. We were one of the few public libraries our size that operated with no filters whatsoever. . . . But it's very, very different to access hardcore porn on a computer where anybody walking behind you can see it. Never again. (Emphasis in original)

Others, however, were more skeptical of Internet filtering and said their libraries did not use filters. Aidan explained, "We don't want to interfere with the intellectual freedom of everyone just to solve a problem that's very localized and specific and doesn't happen all that often." The problem to which he referred was patron viewing of pornography or other inappropriate content. Beth noted that, for very introverted or shy patrons, having to ask a librarian to remove the filter might be too much of a barrier to overcome, and thus those patrons would be left using a filtered Internet. For that reason, Beth was opposed to the use of filters. In addition, she viewed them "as a violation of people's right to access information."

Justin noted that "Internet filtering is thorny for librarians and not very thorny for anybody else." He meant that most community members, as other participants noted, would likely be in favor of Internet filtering because it reduces the occurrence of pornography and other inappropriate content. Librarians, perhaps guided by ALA's arguments, appear more conflicted about Internet filtering.

\section{Meeting Rooms}

All libraries studied here had meeting rooms, most of which were open to the general public. One director reported that her library had so little space and such large programming commitments that the meeting room was in constant use and thus was unavailable for the general public's use. In general, most participants indicated that they had remarkably similar policies about meeting rooms: available to the general public and for nearly any use, including educational, political, and religious purposes. Caveats included that the meetings had to be free and open to the general public and they could not be used as locations for political rallies or fund-raising. This is in line with ALA's guidelines, which state, "If meeting rooms . . . are 
made available to the general public for non-library sponsored events, the library may not exclude any group based on the subject matter to be discussed or based on the ideas that the group advocates" (ALA 2014j, par. 3). The sample policies provided by the KDLA use similar language to ensure that no groups are discriminated against.

Arnold explained the basic line of thought: "We are a public facility and the public has an inherent right to use our meeting space. We could write a policy that said nobody outside the library can use it; I don't think that's a good use of space. You have space going unused then. [But this policy] does open us up: if a KKK group came in and wanted to use the facility, they certainly could, and I made it clear [to the library board of trustees] that I would support their ability to do that."

A few directors noted that the Tea Party political group used library facilities. This was ironic, because, as Janelle said, "They are not friendly to the library because we're a taxing entity . . . but they meet here regularly and I have no problem with that." Individuals affiliated with the Tea Party have been vocal in their opposition to the way that Kentucky libraries are funded, through occasional tax increases (see Warburton, 2013). Nonetheless, library directors unanimously supported the group's right to use library meeting facilities. Luke described receiving phone calls from a liberal political group unhappy with the Tea Party's use of library facilities. Once he explained "I can't deny them use of the meeting room and allow you to have use of the meeting room," he said, "they got it. They still weren't happy about it, though." Jonas summarized the general consensus: "It's inappropriate for us to tell someone what they can or can't say. We don't have to agree with whatever their message is ... [but if] they're not breaking any of our rules or regulations, we don't have the right to deny someone that freedom to meet."

\section{Privacy and Confidentiality}

In general, the library directors indicated that they took patron privacy seriously and had strict policies in place to limit the sharing or exposure of patron information. Most libraries shared two basic components of privacy policies. First, patron records are treated as confidential and not released to law enforcement without court orders, subpoenas, or similar documentation. As Carson said, "It's pretty standard stuff. We won't release patron records at all without a warrant or something along those lines." Second, many participants said they made efforts to keep as few patron records as possible. Beth noted that she had purchased a module for the circulation system that immediately scrubs patron transactions so there are no records. Luke explained, "Our Internet services are set up that after midnight, the search history is gone anyway. I cannot go back and tell you what a patron looked at even if I wanted to."

These two tenets are in line with recommendations from ALA, which advocates for patron privacy, stating "In protecting the privacy rights and the confidentiality rights of library users, librarians, staff, educators, volunteers, and trustees should limit the degree to which per- 
sonally identifiable information is monitored, collected, disclosed, and distributed" (ALA 2014l, par. 4). The ALA also recommends that libraries make patron records available to law enforcement only with proper court orders or other documentation. In addition, ALA states, "In all areas of librarianship, best practice leaves the user in control of as many choices as possible. These include decisions about the selection of, access to, and use of information. Lack of privacy and confidentiality has a chilling effect on users' choices. All users have a right to be free from any unreasonable intrusion into or surveillance of their lawful library use" (ALA 2014k, par. 5).

The KDLA does not have specific recommendations about patron privacy, but it does have suggested policies about records management and retention. It recommends that libraries keep records for the minimum amount of time required by state statue and protect records that have been protected by state statute.

According to the library directors, they have created several processes by which patrons maintain at least some control over their own accounts. Several participants explained that patrons could choose to turn on tracking of their library accounts to keep a record of which books they have checked out; patrons may choose this to remember which books they have read. Other libraries allow patrons to use a third-party system to track their books.

Miles noted that "the parent has some rights in that area," so his library allows parental access to child circulation records. But Tonya had a different view on this: "We won't tell the parents what the kids have out for obvious reasons." When asked to elaborate, she raised a hypothetical situation and said, "If a child comes in and checks out books about child abuse, we're not going to tell the parents."

Other participants reported additional hypothetical situations or real-life occurrences that affected how they viewed privacy in their libraries. Beth told her staff, "What if it's a situation in which a wife and husband are having some problems and she's checked out a book on a doit-yourself divorce?" Julianna noted, "We've had a couple of instances where divorcing parents have battled over kids' accounts and [then] the staff starts seeing firsthand why you shouldn't give that information out." Stanley told the story of a former drug user who turned his life around and then came to the library when faced with temptation, because "I knew you guys could help me." Stanley emphasized that "we want [the library] to be a place where people can come in and say, 'I don't have anyplace else to go; I know you guys aren't going to tell my story to anyone."' Luke recounted that "two women have come to the circulation desk and said that they are abused by their husbands and they were checking out materials about how to leave an abusive spouse. They were asking the question, would we release that information on her record to her husband? And we said, 'Absolutely not; it's totally against our policies."'

In addition to these specific instances that illustrate the importance of patron privacy, the library directors also had more philosophical, general reasons for protecting patrons' information. Julianna explained that "protecting the privacy and the right for someone to come in 
and get what they need, I think it's extremely important because- - how do you say that without sounding strange? - what anybody else reads or why they read something can be misconstrued so easily." Miles added, "A big part, in my head, of intellectual freedom is that anyone can check out whatever they feel is appropriate, and we're not going to share that information with anyone."

Finally, some participants noted that patrons were not always in agreement with the libraries' conceptualization of privacy. Often spouses wanted to use one another's cards or have access to holds or circulation information; parents wanted access to children's accounts as well. Arnold said, "Our patrons will complain that we will not let anybody use another person's card." Janelle described a situation, shortly after the 9/11 tragedy, in which a patron checked out a book about flying aircraft and jokingly said she might end up on an FBI list because of her circulation record. When Janelle assured the patron there was no list and the FBI would not be visiting her, "she went completely 180 [degrees] on me and decided that there should be a list and the FBI should be checking on who was checking out this book" (emphasis in original).

\section{Library Staff and IF}

Many participants (12 out of 15 ) explicitly recognized their staff in relation to IF, both negatively and positively. For example, Julianna noted that sometimes "one of the things we've had to watch for . . . is staff not wanting to buy something because of what might happen." This can be seen as a form of censorship (e.g., Whelan 2009); deciding not to purchase materials for the library because of potential patron concern limits what is available to all patrons. Similarly, Patti discussed a staff member who hesitated to purchase materials that were contrary to her personal views, but Patti pointed out that the books had good reviews and met all the other criteria for inclusion, so they had to be included. Stanley had a staff person who kept hiding a certain children's book because she didn't believe in its message. He insisted the book be placed back on the shelves, saying, "If you editorialize in a way that prevents somebody who needs that information from getting that information ... if you refuse to order something just because you don't like it, you can't work here."

However, most of the comments were quite positive of the staff. The library directors called their staff members "extraordinary," "very well trained," "really great," and "quite strong and experienced." As Aidan said, "I'm lucky to have a staff that really understand[s] what a public library is all about, and they fully embrace that." In this context, he was implying that public libraries are about access to information and IF. Miles explained that he has a "conscientious staff [who] have a broad range of interests and ideas. I think they're in good sync with the community, both adults and children." Participants noted the customer service aspect of working on the "front lines" and helping patrons, particularly patrons who 
had concerns about library material. Staff often received explicit training about how to respond to these concerns - generally by handing them a request for reconsideration form and referring the concerned patron to the director or another senior administrator. Generally, the library directors expressed confidence in their staff and saw their staff as important tools to ensuring IF in the library.

\section{Discussion: The Role of ALA Documents and of Community}

Overall, most participants provided answers remarkably in line with ALA and KDLA guidance. The official policies and statements of these organizations were not cited by the participants and were not quoted verbatim, yet the general interpretations by public library directors echoed the formal interpretations offered by ALA. This congruence may not be surprising, because all but one participant had an MLS (or equivalent) degree and had exposure to ALA statements about IF in library school, in continuing education, and in providing training for library trustees. Even if most library directors could not quote or cite a relevant passage from an ALA document, the general thrust and tenor of these ALA documents is well known and prevalent.

If one reads the literature about IF, however (e.g., Baldwin 1996; Wiegand 1996; Harkovitch et al. 2003), this congruence might be surprising. Several scholars have been skeptical that ALA policies provided much guidance in day-to-day situations that librarians are likely to face. However, the participants in this study seemed satisfied with the common interpretations of IF and were able to apply them, with few problems, in their libraries. Rather than being ineffective, vague statements, ALA and KDLA guidance was implicitly recognized as the foundation upon which these libraries functioned. Divergence from ALA and KDLA policies was relatively rare (for example, see Justin's comment above, about not removing Internet filters upon patron request).

However, the directors did have a focus that is conspicuously absent from ALA policies about IF. All 15 participants mentioned their community, usually more than once, as they discussed IF. It was clear that consideration of their communities was a central concern of these public library directors. Community was always a part of how participants answered questions about IF in their libraries. As they spoke, two perspectives on community emerged.

\section{Community Standards}

The library directors indicated that they thought frequently about community standards in relation to their collections (Edwards et al. 2011). Jonas noted that his library is "a community resource," while Miles discussed "being in good sync with the community, both adults and children." Carson expanded upon this notion: "You always want to cater to all interests and not censor and so forth, but you also have the other piece where you're trying to reflect 
community standards. If this thing is so far across the line, that really it's probably not appropriate for the collection. ... As long as it's not somehow compromising the public good or counter to community standards because, since we're taxpayer supported, that's something you have to consider. That's where the community standard piece comes in." Participants felt an obligation, as Carson indicated, to be responsive to their communities. Luke and Stanley noted that their libraries existed because the communities wanted them-without community support, the libraries' continued existence might be in jeopardy (this is perhaps particularly true in Kentucky, with ongoing lawsuits about the taxing status of public libraries; Warburton 2013). Patti explained that "we often have to develop our collection based on our population, what we think our population can bear and enjoy." Aiden added, "You can build your collection to reflect the needs of the community." Roslyn, when discussing Internet filtering, reasoned that one reason her library used filters was because of the community: "In our community, I think there are more people who would be upset if we didn't [filter the Internet]."

However, the phrase "community standards" cannot be simply understood as a tendency to gather safe, noncontroversial materials. Several participants mentioned that their community standards included an appreciation for intellectual freedom. Stanley said he had never had a formal complaint, which he thought spoke well of his community. He said, "People are, by and large, not going to lose their mind if they see something. They'll come in and talk to me first." Janelle commented, "If you let them know that nobody gets to be the morality police for them, but they also don't get to be the morality police for anybody else, then they start thinking about it from a different direction ... so people are pretty tolerant around here." Arnold noted that his community was "very articulate in their beliefs that the library is for all people and access to ideas in all shapes and forms and expressions." Luke added, "People seem to understand that people have the right to read what they like to read or want to read."

Thus, for these participants, "community standards" was a nuanced, complex conception. On one hand, they had to be responsive to community standards and not spend limited resources on something that would be unlikely to circulate or likely to cause offense; on the other hand, community standards also included a certain measure of tolerance and respect for differing perspectives. Again, this perspective is missing from much of the literature about intellectual freedom and community standards. Often "community standards" is perceived as a code for a bland, nonchallenging, safe collection. However, community standards should also be taken to mean appreciating one's community for its tolerance of diverse ideas. One's community deserves respect, according to the library directors, because the community can often appreciate that the public library serves diverse patrons with diverse backgrounds and needs. This view of community standards is closely related to the second perspective that the participants had of their communities: they saw IF as a way to serve their communities. 


\section{Intellectual Freedom as a Responsibility to Communities}

Participants explained that IF allowed them to serve their diverse communities by providing a justification and an explanation for a diverse collection. For example, Luke said, "We are very big on having a balanced collection and making sure the collection meets the needs of our community." He explained that balance, in this context, included "everything from political issues to religious issues to issues of the day to making sure that the minorities in our community are being taken into consideration." Patti likewise noted that her library's strategic plan "talks about providing information for everyone in the community, regardless of race, age, political or religious beliefs and that sort of thing."

In these interviews, the library directors were very conscious of their diverse communities (even if not racially/ethnically diverse, they were "diverse in their readership," as Stanley phrased it). Patti described an interaction with one patron who was questioning the inclusion of certain books in the library. After Patti explained intellectual freedom to the patron, the patron replied, "I never thought of that; I just saw a library as a library." Patti then answered, "This is the library for the people, for all the people" (emphasis in original).

Participants were equally conscious of the public library's vocation to serve all possible patrons, to have resources for as many people as they possibly could. For these directors, adhering to principles of IF helped justify diverse resources and a balanced collection. As described earlier, several participants defined IF in relation to their community. Janelle said, "The general sense of it is that there are a wide variety of people in this county and they have a wide variety of interests, and we as a popular materials library are going to attempt to meet the biggest majority of those interests as we can. We won't meet them all. . . We might have some interests that are not your interests, but that doesn't mean they aren't valid. So we'll collect whatever we deem appropriate, and you're free to read it or not read it." As this quote illustrates, the participants believed that IF was, in fact, a responsibility owed to the community by the public library. Practicing intellectual freedom enabled these librarians to serve their communities more completely. Aidan added, "If our collection is not causing some controversy in the community, then we don't have a good collection . . . because there is such a broad spectrum of people that live in the community, that you're going to offend people. It's not our intention. But if we're providing a well-balanced collection, we are going to be making people uncomfortable sometimes." This stance goes far beyond most discussions of IF in the existing literature. Although many authors note that providing a broad range of access is an important way that libraries serve their communities, there is no explicit mention of IF in connection with this. The participants, in contrast, saw IF as an integral part of their service to communities.

A similar approach guides these directors' approaches to meeting rooms. Providing meeting rooms with an open policy about who can use the rooms encourages community inter- 
action and involvement and creates opportunities for diverse groups. Jonas noted that his library's meeting rooms were open to any community member to host a meeting on nearly any topic, but "that doesn't mean we agree with whatever the subject matter is, nor do we monitor what the subject matter is." Recall that several libraries allowed activists opposed to library taxation to use library meeting facilities - the library directors believed so strongly in community use that they opened the doors to groups hostile to the library itself.

\section{Conclusion}

This research examines intellectual freedom through interviews with 15 library directors across the state of Kentucky. Participants were generally in agreement with ALA's guidelines on intellectual freedom. This may demonstrate that ALA positions are well represented in library science schools (because 14 out of 15 participants had an MLS degree) or in continuing education (as required by the state). It seems that the stance taken by ALA has been taken up by library directors, at least in this state. For example, the participants strongly believed that they should have a diverse, broad collection to appeal to a wide range of people, and they were willing to defend this approach. Although few explicitly cited ALA documents, the wording and sentiments were quite similar.

However, the library directors' emphasis on community in relation to IF was unexpected. They indicated that IF was tightly coupled with community in various ways. To them, the concept of community standards included an openness to diverse resources rather than being a code phrase signaling a bland, uncontroversial collection. The participants made an even stronger connection between IF and community when they explicitly linked the two, stating that preserving and promoting IF was an integral part of serving their communities. This is an underexplored aspect of IF that deserves attention.

Further research is needed to better understand how library directors conceptualize community, service to their communities, intellectual freedom, and the relationships between these concepts. The ALA argues that IF is a universal concept that can be applied across contexts and communities. However, the library directors interviewed here suggested this is not an accurate depiction of IF in action, in the daily actions and decisions of public librarians. To better capture the way IF is understood in public libraries, ALA should acknowledge its foundation in local communities. Currently, conceptualizations of community are missing from IF at the national policy level, but they are present at the local, enacted level. Public library directors currently have a balancing act to perform, weighing the expectations of a national organization (ALA) with the needs and expectations of their communities. More explicit acknowledgement of this tension, and suggestions for how to address community concerns, would enable ALA to better serve its constituents. 


\section{References}

ALA (American Library Association). 2014a. "Access for Children and Young Adults to Nonprint Materials: An Interpretation of the Library Bill of Rights." http://www.ala.org/advocacy/intfreedom/librarybill /interpretations/accesschildren.

ALA (American Library Association). 2014b. "Banned and Challenged Books." http://www.ala.org/advocacy /banned.

ALA (American Library Association). 2014c. "Challenged Materials: An Interpretation of the Library Bill of Rights." http://www.ala.org/Template.cfm?Section=interpretations\&Template=/ContentManagement /ContentDisplay.cfm\&ContentID=31881.

ALA (American Library Association). 2014d. "Code of Ethics of the American Library Association." http:// www.ala.org/advocacy/proethics/codeofethics/codeethics.

ALA (American Library Association). 2014e. "Dealing with Concerns about Library Resources." http://www .ala.org/bbooks/challengedmaterials/preparation/dealing-concerns.

ALA (American Library Association). 2014f. "Diversity in Collection Development: An Interpretation of the Library Bill of Rights." http://www.ala.org/advocacy/intfreedom/librarybill/interpretations/diversity collection.

ALA (American Library Association). 2014g. "Intellectual Freedom and Censorship Q\&A." http://www.ala .org/advocacy/intfreedom/censorshipfirstamendmentissues/ifcensorshipqanda.

ALA (American Library Association). 2014h. "Interpretations of the Library Bill of Rights." http://www.ala .org/advocacy/intfreedom/librarybill/interpretations.

ALA (American Library Association). 2014i. "Library Bill of Rights.” http://www.ala.org/advocacy/intfreedom/librarybill.

ALA (American Library Association). 2014j. Meeting Rooms: An Interpretation of the Library Bill of Rights." http://www.ala.org/advocacy/intfreedom/librarybill/interpretations/meetingrooms.

ALA (American Library Association). 2014k. "Privacy: An Interpretation of the Library Bill of Rights." http:// www.ala.org/advocacy/intfreedom/librarybill/interpretations/privacy.

ALA (American Library Association). 2014l. "Questions and Answers on Privacy and Confidentiality." http:// www.ala.org/advocacy/intfreedom/librarybill/interpretations/qa-privacy.

Anthony, Carolyn A. 2014. "Knowing Our Communities." Public Libraries 53 (2): 5-7.

Baldwin, Gordon B. 1996. "The Library Bill of Rights-A Critique." Library Quarterly 45 (1): 7-27.

Carr, David. 2011. Open Conversations: Public Learning in Libraries and Museums. Santa Barbara, CA: Libraries Unlimited.

Cohen, Henry, and Mary Minow. 2006. "Intellectual Freedom in Libraries: Then and Now." Advances in Librarianship 30:73-101.

Dresang, Eliza T. 2006. "Intellectual Freedom and Libraries: Complexity and Change in the Twenty-First Century Digital Environment." Libraru Ouarterly 76 (2): 169-92.

Duthie, Fiona. 2010. "Libraries and the Ethics of Censorship." Australian Library Journal 59 (3): 86-94.

Edwards, Julie Biando, Melissa S. Rauseo, and Kelley Rae Unger. 2011. “Community Centered: 23 Reasons Why Your Library Is the Most Important Place in Town." Public Libraries 50 (5): 42-47.

Fallis, Don. 2007. “Information Ethics for Twenty-First Century Library Professionals.” Library Hi-Tech 25 (1): $23-36$.

Foster, Catherine, and David McMenemy. 2012. "Do Librarians Have a Shared Set of Values? A Comparative Study of 36 Codes of Ethics Based on Gorman's Enduring Values." Lournal of Librarianship and Information Science $44(4): 249-62$. 
Fricke, Martin, Kay Mathiesen, and Don Fallis. 2000. "The Ethical Presuppositions behind the Library Bill of Rights." Library Ouarterly 70 (4): 468-91.

Goe, W. Richard, and Sean Noonan. 2006. "The Sociology of Community." In 21st Century Sociology: A Reference Handbook, edited by Clifton D. Bryant and Denis L. Peck. Thousand Oaks, CA: Sage.

Gorman, Michael. 2000. Our Enduring Values: Librarianship in the 21st Century. Chicago: American Library Association.

Harkovitch, Michael, Amanda Hirst, and Jenifer Loomis. 2003. "Intellectual Freedom in Belief and in Practice." Public Libraries 42 (6): 367-374.

Jaeger, Paul T., John Carlo Bertot, Christie M. Kodama, Sarah M. Katz, and Elizabeth J. DeCoster. 2011. "Describing and Measuring the Value of Public Libraries: The Growth of the Internet and the Evolution of Library Value." First Monday 16 (11).

Jaeger, Paul T., John Carlo Bertot, and Charles R. McClure. 2004. “The Effects of the Children's Internet Protection Act (CIPA) in Public Libraries and Its Implications for Research: A Statistical, Policy, and Legal Analysis." Journal of the American Societu for Information Science and Technoloau 55 (13): 113139.

Klinefelter, Anne. 2010. "First Amendment Limits on Library Collection Management.” Law Library Journal $102(3): 343-74$.

Knox, Emily J. M. 2011. "Intellectual Freedom." Public Services Ouarterly 7:49-55.

Knox, Emily J. M. 2014. "Supporting Intellectual Freedom: Symbolic Capital and Practical Philosophy in Librarianship.” Library Ouarterly 84 (1): 8-21.

Lilleker, Darren G. 2003. "Interviewing the Political Elite: Navigating a Potential Minefield. Politics 23 (3): 207-14.

McCabe, Ron. 2003. "The CIPA Ruling as Reality Therapy: The Supreme Court Has Done Librarianship a Big Favor.” American Libraries 34 (7): 16.

Moody, Kim. 2004. “Censorship by Queensland Public Librarians: Philosophy and Practice." Aplis 17 (4): $168-85$.

Morrissey, Judianne E. 2012. "Global Issues and Local Action: The Rights to Intellectual Freedom and Information Access, and What That Means for U.S. Libraries." Codex: Journal of the Louisiana Chapter of the ACRL 2 (1): 36-57.

Oltmann, Shannon M. 2016. "Intellectual Freedom and Freedom of Speech: Three Theoretical Perspectives.” Library Ouarterly 86 (2): 153-71.

Patton, Michael Q. 1987. How to Use Qualitative Methods in Evaluation. 2nd ed. Newbury Park, CA: Sage.

Scott, Rachel. 2011a. "The Role of Public Libraries in Community Building." Public Library Ouarterly 30:191227.

Scott, Rachel. 2011b. "Strategies That Public Libraries Use to Build Communities." Public Library Ouarterly 30:307-46.

Sung, Hui-Yun, and Mark Hepworth. 2013. "Community Engagement in Public Libraries: Practical Implications." Advances in Librarianship 37:31-47.

Sung, Hui-Yun, Mark Hepworth, and Gillian Ragsdell. 2012. "Investigating Essential Elements of Community Engagement in Public Libraries: An Exploratory Qualitative Study." Lournal of Librarianship and Information Science 45 (3): 206-18.

Taylor, Kelly, and David McMenemy. 2012. "Censorship Challenges to Books in Scottish Public Libraries." Journal of Librarianship and Information Science 45 (12): 153-67. 
Warburton, Bob. 2013. “Kentucky Library Suits Threaten District Tax Funding Statewide.” Library Journal, April 18. http://lj.libraryjournal.com/2013/04/litigation/kentucky-library-suits-threaten-district-tax-funding -statewide/\#

Whelan, Debra Lau. 2009. "A Dirty Little Secret: Self-Censorship Is Rampant and Lethal.” School Library Journal 55 (2): 26-30.

Willingham, Taylor L. 2008. "Libraries as Civic Agents.” Public Libraru Ouarterly 27 (2): 97-110.

Wiegand, Shirley A. 1996. "Reality Bites: The Collision of Rhetoric, Rights, and Reality and the Library Bill of Rights." Library Quarterly 45 (1): 75-86.

Shannon M. Oltmann: assistant professor in the School of Information Science at the University of Kentucky. Oltmann earned her PhD from the School of Library and Information Science at Indiana University. Her research interests include freedom of speech, intellectual freedom, information policy, public libraries, and qualitative research methods. Her work has been published in the Journal of the American Society for Information Science and Technology, Libri, and Science and Engineering Ethics. She is part of the multi-institution research team Mapping Information Access. E-mail: shannon.oltmann@uky.edu. 